taking into account their past and present wishes and feelings, the need to encourage their participation in decision-making and the general principle of the "least restrictive option". Carers would not be authorised, except in emergency, to confine an incapacitated person or enforce a decision to which the incapacitated person objected. Carers would be liable in law only if they acted in bad faith or without reasonable care and the offence in S127(2) of the Mental Health Act would be extended to protect all incapacitated people from ill-treatment or wilful neglect by their carers.

A new jurisdiction would extend to people aged 16 years and over with established mental disorder or disability as defined by the Mental Health Act and people unable to communicate who failed a legal test of capacity. This would depend on the person's ability to understand and retain relevant information for long enough to take an effective decision. Mental disorder preventing a person who otherwise understood relevant information from making a "true" choice would also count.

Provisions are also suggested for administrative decision-making and for establishing a judicial authority with extended powers similar to those of the present Court of Protection but covering personal care and welfare as well as financial matters and for modifying some of the "mechanics" of the enduring power of attorney. The Court would have powers to resolve specific issues and to appoint proxies to manage the incapacitated person's personal care and financial affairs.

The main concern for psychiatrists is the need to establish the presence of mental disorder and whether this should be done by a "registered medical practitioner" as the document suggests or whether it should be done by a doctor approved under the Mental Health Act. The whole tenor of the document is to deal with matters at the simplest level possible and to avoid judicial procedures whenever possible. Nevertheless, we might expect some increase in demands upon psychiatrists' time if this worthy document's provisions are eventually enacted.

J. P. WATtIS

Senior Lecturer (Psychogeriatrics)

St James University Hospital

Leeds LS9 $7 T F$

Let There be Light Again: A history of Gartnave Royal Hospital from its beginnings to the present day. Pp. 130. 1993. £5 plus postage and packing. Available from: Eileen Ross, Voluntary Services Organiser, Gartnavel Royal Hospital, 1055 Great Western Road, Glasgow G12 OXH

Hospital histories usually appear at some significant anniversary. For Gartnavel Royal, 1993 marks 150 years of its existence on the present site, although its first building, elsewhere in Glasgow, dated back to 1814 , and its Royal Charter was granted only ten years thereafter. The original foundation was established by public subscription, whereas some other Royal asylums owed much, or all, to individual philanthropists like the pioneering Susan Carnegie in Montrose in 1781. However, the citizens of Glasgow responded with generosity, and adequate funds were raised. With expansion and relocation, however, the hospital finances were later much burdened by debt.

There are different approaches to this kind of history. On the one hand there is the meticulous annual account as in the magisterial Easterbrook and, later, Turner Chronicle of Crichton Royal. On the other, extracts from hospital records can be used to enhance a wider essay on psychiatric and cultural history, a plan used by Whittet and MacLeod for the centenary volume of Craig Dunain in Inverness.

A "thematic survey" has been adopted here, with multiple authorship of three psychiatrists, and one psychologist, chaplain, nurse and medical historian. The essays cover Administration and Finance, Religion and the Chaplaincy, Environment of Architecture - "environment" being liberally interpreted, Medical Officers and Therapeutics, in two sections for before and after the arrival of (Sir) David Henderson in 1921, Keepers to Carers, referring to nursing; and the patient population. There is some overlap, but this helps to keep these rather arbitrary divisions interesting, and each essay stands easily on its own.

Naturally, there is comment on some periods when management and treatment were strange to modern eyes. Like other Royal asylums, Gartnavel catered for both paupers and minimally paying patients. Architecturally, West House was for the latter, and the less attractive and worse furnished East House for the paupers. By the end of last century, these patients had been relocated in the newer District Asylums, and the paupers' house accommodated other categories, including, in this reviewer's time, junior doctors.

For medical treatment, it is wise to remember that many psychiatrists of today may have limited experience of psychotic end states, and thus may be less able to appreciate the major problems their predecessors faced. Treatment policies were understandably dictated by the Physician Superintendents with individual attitudes. Much is made of David Yellowlees' strong views of physical control and organic causation, but the balance is maintained by some references - for example his advocacy of female nurses in male wards-to the intimate domestic atmosphere of hospitals then. (One of Yellowlee's distinguished sons insisted he began his psychiatric career at the age of six months, being placed by his mother in the arms of a melancholic patient). 
It is good to see these two great figures, Henderson and his successor Angus MacNiven, bracketed together. The authors could not resist reference to MacNiven's alleged eccentricity in "the popular Gartnavel mythology", and quote one of the famous tales; but some who knew MacNiven came to believe these were secretly fostered, if not indeed invented, by that eminently sane but very subtle Highland gentleman. He combined a selfless and effective devotion to his patients with a wryly witty selfdepreciation, a trait not common in distinguished doctors.
This is a good book, well written, illustrated, and extremely cheap. The history of a fine hospital may even be of some current relevance in these days of bed closures and community care. Andrews, in the very last sentence of the book, wisely writes "The benefits and drawbacks of such changes at Gartnavel Royal and elsewhere - and patients' own views of them - will, more than likely, only become clear in subsequent generations".

A. C. TAIT

Formerly Physician Superintendent

Crichton Royal Hospital, Dumfries, Scotland

\section{List of assessors}

The editors of the Psychiatric Bulletin would like to thank the following who have acted as specialist assessors during the past six months.

$\begin{array}{llll}\text { D. Abrahamson } & \text { J. A. T. Dyer } & \text { N. L. Holden } & \text { G. Pullen } \\ \text { C. E. Adams } & \text { K. Ebmeir } & \text { L. Ions } & \text { J. Race } \\ \text { G. Andrews } & \text { L. H. Fagin } & \text { R. G. Jezzard } & \text { F. Reader } \\ \text { L. Appleby } & \text { A. Farmer } & \text { D. Johnson } & \text { S. Ritter } \\ \text { B. Ballinger } & \text { R. Farmer } & \text { D. J. Jolley } & \text { J. Roberts } \\ \text { G. E. Berrios } & \text { P. Fenwick } & \text { O. Junaid } & \text { T. D. Rogers } \\ \text { S. Bhate } & \text { E. Finch } & \text { C. A. Kaplan } & \text { H. R. Rollin } \\ \text { D. Bhugra } & \text { J. Fisk } & \text { C. L. E. Katona } & \text { O. Russell } \\ \text { D. Black } & \text { D. G. Fowlie } & \text { R. F. Kehoe } & \text { L. Scarth } \\ \text { N. Bouras } & \text { W. Fraser } & \text { A. M. P. Kellam } & \text { D. Scott } \\ \text { P. M. A. Bowden } & \text { P. Freeling } & \text { P. Kennedy } & \text { J. L. Scott } \\ \text { W. D. Boyd } & \text { C. P. L. Freeman } & \text { G. E. Langley } & \text { M. A. Serfaty } \\ \text { W. F. Bynum } & \text { E. Garralda } & \text { R. Levy } & \text { J. Smith } \\ \text { H. R. Cattell } & \text { I. Glass } & \text { M. H. Lim } & \text { D. Somekh } \\ \text { J. Chick } & \text { A. Gath } & \text { C. S. Littlejohns } & \text { R. S. Stern } \\ \text { D. Chiswick } & \text { A. Ghodse } & \text { R. Littlewood } & \text { M. Tannahill } \\ \text { J. Coid } & \text { A. T. Grounds } & \text { R. M. Lyall } & \text { D. Tantam } \\ \text { J. L. Cox } & \text { M. Greenberg } & \text { A. A. McKechnie } & \text { D. Thompson } \\ \text { J. Cookson } & \text { J. Greenwood } & \text { F. Margison } & \text { G. J. Thornicroft } \\ \text { J. L. Crammer } & \text { A. Hall } & \text { S. Montgomery } & \text { P. Tyrer } \\ \text { A. David } & \text { M. A. Harper } & \text { J. O'Hara } & \text { J. P. Wattis } \\ \text { K. Davison } & \text { J. Higgins } & \text { R. L. Palmer } & \text { J. A. Whitehead } \\ \text { K. A. Day } & \text { K. Hawton } & \text { C. M. Parkes } & \text { S. Whyte } \\ \text { C. Dean } & \text { J. L. Herzberg } & \text { S. Payne } & \text { S. R. Wilson } \\ \text { J. Devoy } & \text { P. Hoare } & \text { A. J. Pelosi } & \text { R. Wrate } \\ \text { L. Drummond } & \text { S. R. Hirsch } & \text { J. S. Pippard } & \text { A. J. Yellowlees } \\ & & & \end{array}$

